DOI https://doi.org/10.30525/978-9934-26-004-9-125

\title{
КАМЕРНИЙ ХОР «ОРАНТА» ЯК РЕПРЕЗЕНТАНТ АКАДЕМІЧНОГО ХОРОВОГО МИСТЕЦТВА ВОЛИНІ
}

\author{
Кухарик Г. М. \\ викладач кафедри хорового диригування та постановки голосу
}

Степанюк А. В.

викладач хорового диригування

Комунального закладу вищої освіти «Луцький педагогічний коледж»

Волинської обласної ради

м. Луиььк, Украӥна

Домінуючим видом музичного мистецтва в Україні є хоровий спів. Століттями складався фундамент хорової співацької культури, в якій вміщені усі вікові традиції народу. Таким чином, на даний момент найбільшого розквіту зазнали ті види мистецтва, що глибинно пов'язані 3 прадавніми традиціями, а саме хоровий спів став популярним видом академічного музичного мистецтва.

Найвідомішим академічним хоровим колективом Волині $\epsilon$ Архієрейський хор Луцького Свято-Троїцького собору, камерний хор «Оранта». Хор займається популяризацією української церковної та світської музики в державі та за кордоном. Колектив багатий великою кількістю репертуару, різноманітного за жанровою основою. Художній керівник і диригент В. Мойсіюк віддає перевагу творам А. Веделя, Дж. Верді, та сучасного композитора Г. Гаврилець. Серед відомої духовної музики хор «Оранта» виконав хорові концерти «Хай воскресне Бог», «Приидите, воспоим», «Господи, силою Твоєю», «Тебе, Бога, хвалим» Д. Бортнянського, «Покаяння відкрий мені двері», «Слышы, дщи и виждь» А. Веделя, «Радуйтеся, праведнії», «Не отвержи меня во время старости» М. Березовського, «Тіло Христове прийміте» М. Дилецького, «Внуши Боже молитву мою», «Нащо ти відкинув єси» О. Архангельського, також «Святий Боже» В. Тиможинського, «Отче наш», «Ave Maria» I. Стравінського, «Боже мій, нащо мене Ти покинув», «Тебе поём» Г. Гаврилець, літургії М. Леонтовича, К. Стеценка. М. Вербицького та багато інших [1, с. 105].

Чимало світової класики знаходиться в репертуарі колективу «Реквієм» Дж. Верді, Меca G-dur Ф. Шуберта, «Милість миру» 216 
А. Вівальді, «Милість миру» В. А. Моцарта та багато інших. Хор виконує музику таких українських композиторів як $Є$. Станкович «Заключне Купайло», Л. Дичко - «Колядки», О. Яковчука «Щедрівка», В. Зубицького «За нашим столом», М. Гобдича «Порізала пальчик», О. Некрасова «Весілля мухи», В. Тиможинського «Моя одинокая зірка», «Купайло», «Кривий танець», «Дві прелюдії», кантата «Ой у Луцьку, славнім місті», В. Герасимчука «Вечірня година» та багато інших [2, с. 8]. «Вибираючи репертуар, я намагаюсь вдовольнити та зацікавити усю публіку. Звичайно, коли йдеться річ про конкурс, то використовуються значно складніші твори, щоб показати рівень майстерності для журі. Загалом, я не ганяюсь за складністю, я намагаюсь віднайти красу внутрішню», - сказав у процесі особистого інтерв'ю заслужений діяч мистецтв України В. В. Мойсіюк.

Щоб осягнути етапи діяльності колективу та усвідомити значимість хору для волинської та української культури, звернемося до його історії. Хор «Оранта» був заснований в 1990 році у Луцькій ХрестоВоздвижнецькій церкві і складався 316 учасників. Це викладачі музичних шкіл, педагогічного, музичного та культурно-освітнього училищ та працівники інших закладів культури. Через два роки склад колективу збільшився до 24 осіб та набув статусу хору Луцького СвятоТроїцького собору [1, с. 107]. «Хор „Оранта” став незабутнім епізодом у моїй творчій біографії...Це була різдв'яна поїздка до Австрії у Відень. 25 грудня чоловічим складом хору у місцевій мерії виконали колядки а також відслужили літургію в автокефальній греко-католицькій церкві. Колектив став для мене своєрідним відкриттям. Хор достойний уваги не лише в рамках регіону, а й світу..», - поділився 3 нами спогадом В. А. Чепелюк, народний артист України.

Керівником «Оранти» є випускник Київської державної консерваторії імені П. І. Чайковського класу Михайла Бєрдєннікова, завідувач диригенсько-хорового відділу Волинського державного училища культури і мистецтв імені І. Ф. Стравінського, керівник академічного хору Інституту мистецтв Східноєвропейського національного університету імені Лесі Українки - Василь Васильович Мойсіюк [3, с. 101].

За словами В. Мойсіюка, деякий час колектив мав назву Архієрейський хор Свято-Троїцького кафедрального собору міста Луцька. Та, оскільки у репертуарі почали з'являтися твори світського характеру виникла потреба нової назви. Було чимало ідей, наприклад, «Доброслав», «Нащадки Володимира», «Відродження», та все ж «Оранта», що з грецької означає «та, що молиться», найбільше прийшла до душі митцям.

Розвиток творчої діяльності хору відбувався в нових політичних та соціокультурних умовах, які зумовлені зростанням ролі церкви, 
громадських установ в культурно-мистецьких процесах, появою цілої плеяди композиторів таких як, Леся Дичко, Свген Станкович, Віктор Степурко, Володимир Зубицький, Юрій Алжнєв та багато інших. У період Незалежності України національне хорове мистецтво розповсюджується у світовому та європейському соціокультурному просторі. Також зазначені роки характеризуються дільністю метрів хорового мистецтва, диригентів - Павла Муравського, Віктора Іконника, Анатолія Авдієвського, Свгена Савчука, Олександра Тарасенка, Миколи Гобдича, Лариси Бухонської та багатьох інших [2, с. 15].

Величезну роботу провели орантівці, шукаючи україномовні партитури, оскільки у дев'яностих було проблемно знайти твори, написані національною мовою. Та все ж, за допомогою прихожан, які приносили ноти колядок, щедрівок українською мовою 1900 року видання, а також твори, видані за окупацієї Польщею Західноукраїнських земель упорядниками Завітневичем та Гноєвим виконано безліч прекрасних творів. Партитури надсилали з усієї України, Польщі, Канади та США. У Луцьку була знайдена Літургія М. Тележинського. Також україномовні партитури були надіслані першим регентом Хрестовоздвиженської церкви [3, с. 102].

Під час плідної творчої діяльності колектив чимало гастролював популяризуючи, таким чином, українське хорове мистецтво. За 30 років клопіткої роботи камерний хор «Оранта» прославив Волинь на таких престижних мистецьких акціях як, міжнародний конкурс імені Лесі Українки в м. Луцьку $(1994,1996,2006)$, імені М. Леонтовича в м. Києві (2002), церковних хорів у Львові (1991), церковної музики в м. Гайнувці (Польща, 1998), в м. Фівізано (Італія, 1999), міжнародних фестивалях імені Дж. Верді у Детмольді (Німеччина, 2004), «Саја Salamanca у Soria» (Іспанія, 1997), мюзік-фесті «Золотоверхий Київ» (2001). Визначним у біографії колективу є виконання Реквієму Дж. Верді у 2004 році $з$ двома хорами Детмонду, польським колективом та солістами 3 Тайваню, Болгарії, Німеччини. Камерний хор «Оранта» виконав Всенічну у Володимирському кафедральному соборі та Літургію в соборі святої Софії у Києві, Літургію в Яблучинському православному монастирі в Польщі. У 1995 році під час фестивалю слов'янської культури колектив дав два концерти для української діаспори у місті Гданську, Слупську та Вейхорові, у 2006 році виступив у Хелмі на святкуванні 120-ї річниці 3 дня народження першого президента України - Михайла Грушевського [3, c. 103].

Хор «Оранта» $є$ візитівкою академічного хорового мистецтва Волині. Колектив проводить активну концертно-гастрольну діяльність, популяризуючи українське хорове мистецтво у світовому вимірі. Та насамперед відомі та обожнювані місцевим населенням хористи 218 
забезпечують своїм співом духовний спокій та відчуття піднесення під час служб в Свято-Троїцькому соборі. Керівник хору - талановитий митець, професіонал своєї справи успішно реалізує завжди вдало підібраний репертуар, швидко та якісно справляється 3 любими труднощами. Мабуть, саме тому хор «Оранта» $€$ завжди успішним та цікавим як для широкого загалу так і для спеціалістів мистецького кола.

\title{
Лiтература:
}

1. Марач О. М. Церковне хорове мистецтво Волині в добу державної Незалежності України. Украӥнська культура: минуле, сучасне, иляхи розвитку. Рівне. 2011. Вип. 17. С. 102-108.

2. Марач О. М. Академічне хорове мистецтво у соціокультурному континуумі західного регіону України періоду незалежності (на прикладі Волині): автореф. дис. ... канд. мистецтвознав. Львів, 2013. 17 с.

3. Тиможинський В. А., Шиманський П. Й., Новакович М. О., Єфіменко А. Г., Бернацька Г. О. Музичне мистецтво Волині XIX-XX століття: колективна монографія / за ред. П. Й. Шиманського. Луцьк: Твердиня, 2012. 168 с.

DOI https://doi.org/10.30525/978-9934-26-004-9-126

\section{ВОКАЛЬНА ТВОРЧІСТЬ СТАНІСЛАВА ЛЮДКЕВИЧА В КОНТЕКСТІ ЙОГО НАУКОВО-ПЕДАГОГІЧНОЇ ДІЯЛЬНОСТІ}

\author{
Михайлова О. Ю. \\ викладач вокалу II категоріі \\ Соиіально-гуманітарного управління виконавчого комітету \\ Комунального закладу «Богуславська школа мистецтв» \\ Богуславської міської ради Київської області \\ м. Богуслав, Київька область, Украӥна
}

Розбудова нашої незалежної держави неможливе без відродження національної культури, традицій українського народу, без піднесення його духовності й національної гідності. Серед усіх діячів музичної культури причетних до освіти та виховання молоді на національній основі значне місце належить Станіславу Людкевичу.

Життя та творчість С.П. Людкевича це приклад безкомпромісного служіння музиці, предметний урок композиторської та загальнолюдської етики. Безпосередне відношення композитора до музичного навчання та виховання дітей шкільного віку. Ще на початку XX ст. він визначив 